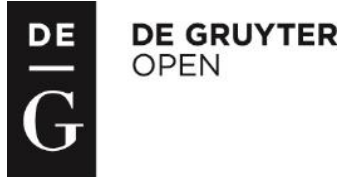

\author{
${ }^{*}$ Laleh Atashi \\ Department of Foreign Languages and Linguistics, \\ College of Literature \& Linguistics, Shiraz University \\ Eram Square, Eram Pardis, 71946, Shiraz, Iran. \\ e-mail: latashi@rose.shirazu.ac.ir
}

\title{
THE STATUS OF WILLIAM CARLOS WILLIAMS IN AMERICAN MODERNISM
}

\begin{abstract}
William Carlos Williams was an American poet who renounced poetic diction in favor of the unpoetic, establishing himself in American Modernism as a powerful voice distinct from such canonical contemporaries as T.S. Eliot and Ezra Pound. His attitude towards literary production was different from many of his contemporaries in that he believed 'the idea is in the thing' and therefore the presence of objects rather than abstractions is strongly felt in his poems. A critical survey of Williams' poems indicates that the poet/physician observes, describes and levels criticism at his society where modernism has transformed the American identity in significant ways. In this article, American icons and popular culture are retraced in the poetry of William Carlos Williams in an effort to explain the seeming opacity of his poems.
\end{abstract}

Keywords: William Carlos Williams, American identity, Modernism, Icon, Popular Culture

Introduction

Morgan, in 1947, points to the influence of imagism and free verse on Williams and divides his images into natural scenes, and urban and suburban human scenes. Solt, in 1962, explains the relationship between language and objective reality that Williams highlights in his poems in order to capture "tones and movements that are distinctively American" (304). Weatherhead, in 1966, discusses the significance of poetic form in Williams' poetry and claims that although it is hard to distinguish poetry from prose in Williams' literary poetics, the use of rhythm in a poem is what Williams considers the most important distinguishing feature that separates the domains of poetry and prose. Breslin, in 1967, traces the influences of Walt Whitman on Williams' poetry and goes on to highlight the features that distinguish Williams from his more refined contemporaries. His involvement in and fascination with the ordinary life, claims Breslin, made him distinct from other poets who adopted god-like vantage points. Hofstadter, in 1977, gives a survey of Williams' later poetry and refers to the pensive tone that the poet adopted towards the end of his life. The poet, Hofstadter notes, contemplates over images of death and defeat in the later phase of his poetic career. Gee, in 1985, refers to Williams' definition of universal art and defines it as "the authentic rendering of the object in all its immediacy and particularity" (375). He creates a link between Russian formalist aesthetics and Williams' formulation of great art. Moore, in 1986, holds that the self conscious ungrammaticality in Williams' writings, as well as his preference for the American speech make sense in a context where scholastic philosophy and logic came under severe attacks. Menzin, in 2014, analyses Williams' poetry and prose and holds that the cubist images and broken pieces in William's writings metaphor the notion of disintegration and loss of coherence in the modern world. This review of literature reveals that the researches that have been done so far on Williams, though very informative, have seldom adopted the viewpoint of cultural studies. This research is an attempt to read and interpret the poetry of Williams within the cultural panorama of American modernism.

\footnotetext{
* Dr. Laleh Atashi is Lecturer of English literature at Shiraz University, Iran. Her work focuses on cultural studies, literature and painting and children's literature.
} 
On first reading, poems such as "Red Wheelbarrow" and "This is Just to Say" might sound inconsequential unless one probes into the American cultural arena at the beginning of the $20^{\text {th }}$ century when William Carlos Williams composed his poems. A historicized view of the cultural significance of the literary text highlights the fact that the study of popular culture, and the study of literariness understood as a meaningfully distinct discourse and practice are not necessarily exclusive or incompatible. Greenblatt comments on the intertextuality of cultural productions:

\begin{abstract}
Cultural analysis has much to learn from scrupulous formal analysis of literary texts because those texts are not merely cultural by virtue of reference to the world beyond themselves; they are cultural by virtue of social values and contexts that they have themselves successfully absorbed. The world is full of texts, most of which are virtually incomprehensible when they are removed from their immediate surroundings. To recover the meaning of such texts, to make any sense of them at all, we need to reconstruct the situation in which they were produced. Works of art by contrast contain directly or by implication much of this situation within themselves, and it is this sustained absorption that enables many literary works to survive the collapse of the conditions that led to their production. (Greenblatt, 1995: 227)
\end{abstract}

William Carlos Williams is one of the modern American poets in whose poems the interaction of culture and literature can be closely observed. Mark W. Van Wieinen uses the term "embedded" to describe modern American poetry's relationship to everyday life as people encountered a huge variety of verse in daily newspapers, magazines, scrapbooks, autograph books, classroom readers, songbooks and advertisements, on the radio, billboards,... and across a host of consumer goods ranging from postcards to calling cards, playing cards, matchbooks, posters, calendars, stickers, menus, pin-ups, and souvenir pillows (qtd in Chasar, 2007: 15).

Popular culture is the site of social transformation wherein the activities of the people are disciplined or incorporated into the dominant power bloc and where people resist or frustrate that discipline and incorporation; it is, in fact, the ground on which the transformations are worked. Therefore, in order to understand modern American poetry, one must be willing to look for and seriously read poetry conceived in the political, economical and social fabric of modern America. The poetry embedded in popular culture and everyday life was harnessed by the United States culture industries. Popular culture, Baker explains, is "an arena where cultural hegemony is secured or challenged" (2004: 148). Thus, popular poetry, like other discourses, encourages the American folk to take part in the discursive practices of the capitalist America. This trend can be traced in Williams' poetry and also in his efforts to articulate the poetics of modern American poetry:

In our speech, in other words, we should be technically trying to discover hints at a line adequate to the very complex configuration of the modern mind which does not readily adapt itself to the older verse form conventions - which really by their mediaeval associations thwart us in our attempts at poetic statements. The difficulties are great; the rewards might be greater if we could bring ourselves squarely to face the problem - of a really modern, measurable, verse form. (Williams, 1997: 161)

Williams insists on simple understandable poetry and reacts to the philosophical complexities; he believes that modernism had at its base a commitment to "the reality of the word", and to the dominance of language over ideas: "Poor simple Shakespeare, what a[n] ass he was compared with almost any shitty little philosopher of today" (ibid). Williams rejects the conception of the poet as someone sitting in the ivory tower of literature, using an elitist discourse in their literary productions, never caring to establish a common ground between themselves and their contemporary audience. By contrast, he emphasizes the significance of choosing the concrete and tangible as the subject matter of poetry:

Subject matter? Anything. But nothing upon which the senses have not struck directly. That is to say you won't build readable verse today on what you've never experienced, never come into contact with, know nothing about. And what you have encountered, on the other hand, what you have knocked against, stumbled over, engaged in your contests must be admitted, can't be excluded. (ibid) 
The language used by Williams, as can be seen in the quotation above, had a crabbed grammatical quality that North defines as "his dissonance, his slantwise relationship to the linguistic world around him" (North, 1994: 151). Williams offers some do's and don'ts to help the formulation of a typically American criterion for literary criticism. Furthermore, he votes for the discarding of the European rhetorics in favour of American democratic values, because they promise an intensity of vision that the British vantage point lacks: "And this is the opportunity of America! To see large, larger than England can" (Williams, 1954:86). He rejects the "aesthetics of precision for the rhetoric of inclusion" (Sayre, 1989: 329). His poetic landscape, therefore, consists of a collage of different voices.

The Influence of the Discourse of Progress: Verticality and Mobility

In order for a modern American identity to be fermented, skyscrapers replaced the colonial bungalows, and cowboys and horses of the previous centuries gave way to the riders of the Ford automobile. The effects of this transition can be traced in a selection of Williams' poetry produced during 1920s and 1930s. What makes his poetry typically modern and American is the influence of the illiterate Jazz culture grounded by the marginalized population of Harlem. Another typical display of Americanism in Williams's poetry is his participation in the consumer culture. Mobility as an indispensable part of the American identity ${ }^{1}$ is an inspiration for Williams, and its influence on the way man looks at life can be traced in the vantage points his speakers take.

American identity during the time following the First World War, the time during which Williams produced "Spring and All" in 1923, was informed by mad driving, jazz music, and science's galloping progress. Breaking loose from the old British yoke -- especially after the First World War -was a mission carried on by the producers of the American culture: designers of architecture, automobiles, economy all took it upon themselves to produce purely American products that would lead to the formation of American icons. The analysis of architectural discourse in early $20^{\text {th }}$ century was informed by the tenets of the ideals of democracy, which are expressed in architecture and poetry. Fundamental differences between the older, European ideas of democracy are matched up against the American ideal of competition.

The American skyscraper replaced the colonial bungalows, the word itself being of "Eastern derivation, coming from the Bengali, bangla, signifying a low house with galleries or porches all around, and identical with the Hindi or Hindustani adjective, bangla, "belonging to Bengal." An article in American Architect and Building News, in 1908 characterizes the "dak-bungalow" as "a house for travelers" (Lancaster, 1958: 239). The concept of temporality at the heart of the word "bungalow" is brushed aside by the root-establishing penetration of the phallic skyscrapers into the American ground. Therefore, New York builders, unlike Boston and Chicago who adopted strict height regulations in order to emphasize and imitate European aesthetics, "sought unregulated commercial expansion and an architecture advertising wealth and prestige" (Gilfoyle, 1998: 180), represented by the tall building.

The American ambition to form an architectural identity, therefore, was realized in the turn from the horizontality of the bungalow to the verticality of the skyscraper. The upward movement in architecture finds its parallel in the culture of mobility and speedy onward movement. The ideal of progress in the early $20^{\text {th }}$ century was brought about by the surging scientific, medical and technological developments: the modern poets and artists of the time, Williams one of them, probably felt: "very excited about the future because scientists were making many new discoveries, and the new technologies of the photograph, the telephone, the bicycle, and the automobile were exciting great interests". Consequently, Ezra Pound recognized that the rapid transformations of twentieth century science and technology made new demands on poets and that romantic verse could no longer meet the new social and cultural requirements (Middleton, 2006: 213-14). Articles have been written on gaze and sexual politics in the poetry of Williams. Sharon Dolin, for example, in an article entitled "Enjambment and the Erotics of the Gaze in Williams's Poetry" notes that it is "the reader who creates meaning by visually parsing a poem's lineation and thus participates in a visually (versus aurally) grounded aesthetic -which presupposes an erotics of the look, or gaze" (Dolin, 1993: 29). Jon Chatlos in "Automobility and Lyric Poetry: The Mobile Gaze in William Carlos Williams' 'The Right of Way',"

\footnotetext{
${ }^{1}$ Mobility was an anti-establishment policy in the Wild West, a mode of life led by the wandering cowboy, a version of the American Adam.
} 
claims that the images that the male speaker sees "subtly suggest a 'passing narrative' of voyeurism" (154). But the gaze in William's poetry can be looked at from another point of view. The skyscraper was the representation of the discourse of height in the modern American culture:

With the sole aim of housing the greatest number of people in the least amount of space; verticalism signified proud capitalism. Once skyscrapers began to be less vilified as social nuisances and recognized instead as having an independent aesthetic value, they were endowed with individual qualities. They became modern icons testifying to the individualistic spirit of American capitalism. (Wigoder, 2002: 157)

The godlike omniscient vantage point it provided was rooted in the typically American quest for unlimited economic progress. Having the upper hand in the interaction with the surrounding world results in the indispensable gaze enjoyed by Williams' speakers dominant in his descriptive poems. This vantage point can best be witnessed in William's flower poems such as "The Crimson Cyclamen (To the Memory of Charles Demuth)":

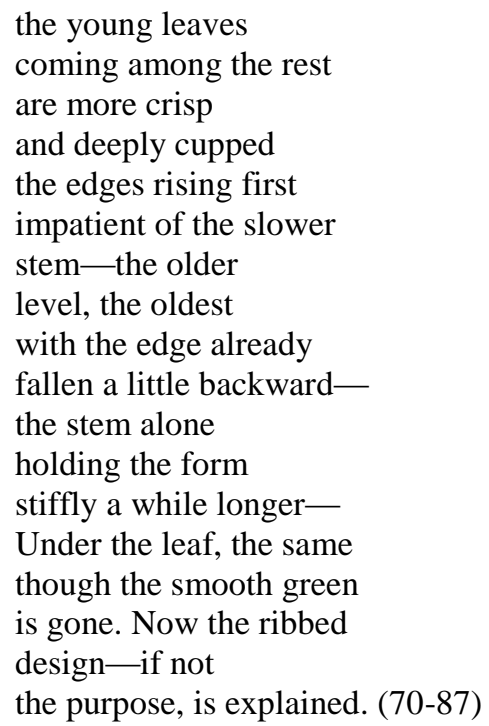

In this poem, the point of view from which the poet looks at the flower is boldly omniscient, this is intense seeing, seeing from different angles, different distances, from the present and the past tense (the setting shifts from winter to September), seeing not just old and young leaves, but older and oldest leaves, seeing leaves in various stages of the life cycle, emerging, withering, seeing as a mixture of understanding, explaining, and probing. Therefore, the discourse of height provides the American with a god-like authority to look at the world.

To be modern, in the American psyche, was to drive your life ahead in the car of technological or cultural change. Marchand in his examination of the advertisements of the 1920s and 1930s observes that portraits of the young generation of the era were used to celebrate the modern culture against a resisting old generation: "to confirm their distance from modernity, the elderly never appeared in explicitly urban settings. In advertising stereotypes the elderly were neither mobile nor modern. Nearly always seated, they found their place among nostalgic props like fireplaces and kittens" (Marchand, 1985: 182). Such advertisements were committed to show the break away of the young America from the old past. Some concepts of modernism in the United States included the sense of forward-looking contemporaneity (Wilk, 2006:2), the belief in the power and potential of the machine and industrial technology (Wilk, 2006: 3) and the emphasis on process (Kouwenhoven, 1998: 133-136). The democratic -- perhaps commercial -- possibilities of the car were first demonstrated by Henry Ford, a restless Michigan Irish farm boy. Ford had mesmerized Americans and provided them the chance to quench their thirst for mobility. In "Ballad of Faith" for example, automobile has been elevated to a high position, a position sought by any American individual in search of prestige: 


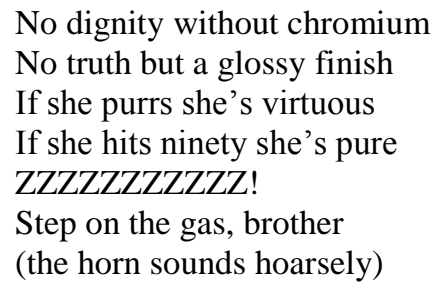

The euphoria of mad driving was embedded in the psyche of the post war generation. The young generation of the 1920s turned into heavy drinking, speed cars and raucous music. The brand new car, therefore, informs the identity of this generation. The shining color of the cars and the noise produced by them and their shrilling horns were indulgences enjoyed by a shell-shocked generation trying to reconcile as far as they can with their surrounding world. In "To Elsie" for example, the absence of drivers has paralyzed the society:

\author{
As if the earth under our feet \\ Were \\ An excrement of some sky \\ And we degraded prisoners \\ Destined \\ To hunger until we eat filth \\ $\cdots$ \\ No one \\ To witness \\ And adjust, no one to drive the car (49-66)
}

Mobility, as was mentioned before, represented the idea of process and progress. The horse-riding cowboys' refusal to be pinned down to domesticity before the upsurge of machines in the American life and the reckless drivers of the 1920s were different versions of the same type within the myth of America: that of restless man on a quest. Automobiles had a place within prophetic statements about the future of the country: "during the modern time utopian observers predicted that motor vehicles would replace horses in American life" (Wells, 2007: 499). Therefore, the dystopian picture Williams depicts of America as "An excrement of some sky," takes place when there is "no one to drive the car". The consequent stagnation is the root of identity loss in the American culture.

\title{
The Influence of Harlem Renaissance and Black Culture
}

Jazz, the music of the roaring twenties had a great influence on the cultural products of America. Jazz was called the "folk music of the machine age" by Whiteman (1927: 4). Jazz music, produced by the black labour class that was free from the formal European musical education, was a proper medium for the improvisation of emotions and moods of a community whose main enterprise was producing a distinct identity of its own. Jazz music had within itself the heterogeneous quality of the nation out of which it emerged: Irving Berlin comments on jazz as the "American folk music" and highlights the influence of "old southern songs" and the "negro spirituals", and "Russian and Italian folk songs" on jazz to reveal its receptive nature ("Berlin Calls Jazz American Folk Music", 1925: 2). Therefore, jazz music blends the cultural identity of the black people with other immigrant influences but still, due to its improvisational aspect, it gives enough space to individuals to improvise their distinct identity. As a result, the tendency toward integration and assimilation does not eliminate the pluralism of an individualistic culture and that's what makes jazz distinctly American.

Shirly Brice Heath characterizes William's poetry as "incomplete sentences, mixed genres, numerous openings of subgenres without closures of these, repetitious false starts, switches across topics within the midst of paragraphs, incomplete or unclear pronoun reference, incomplete references to other actual texts upon which this text depends, and direct dialogue cited without indication of speaker" (1985: 287). Such qualities are those of oral discourse rebelling against the written discourse. The rebelling of informal against the formal in literature and poetry goes parallel with the rebellion of the American youth against the old establishment imposed on America by the colonial presence of 
Britain. In "The Rose", Williams describes the replacement of an old rose by a new rose, using images of sharp, edgy surfaces and cutting imageries:

\author{
Sharper, neater, more cutting \\ Figured in majolica- \\ The broken plate \\ Glazed with a rose (14-17)
}

The new rose, no matter how fragile, uproots the old rose and replaces it: "the fragility of the flower/ unbruised/penetrates space". The onward or let's say upward movement of the fragile flower represents the aspiration and hope of a generation of Americans whose aim was to establish a distinct identity against the obsolete presence of the old establishment. Singal notes that the aim of American modernism was to "integrate once more the human and the animal, the civilized and savage, and to heal the sharp divisions that the nineteenth century had established in areas such as class, race, and gender"(13). Williams translates the American impatience with the ordinary boundaries into informal speech rhythm, particularly in "Shoot it Jimmy":
Man
Gimme the key
And lemme loose
I make 'em crazy

The elisions in this part, the reluctance to acknowledge the normal/formal distance between words show the predilection for merging and integration. "Shoot it Jimmy" is spoken by an impatient individual who is eager to express his/her unique identity:

\author{
Nobody \\ Nobody else \\ But me- \\ They can't copy it!
}

Musical composition is what the speaker is boasting of, that is, he wants to express himself via music among all other arts. The importance of musical originality, consciously chosen by Williams as the proper medium for self-expression is significant in that the black culture influence in American modernism comes to the fore. The originality achieved by improvisation informed the identity of jazz music fashionable during the 1920s in Harlem. Harlem renaissance was a great influence on the American modernism. The black people tried to free themselves from the stereotypical identity imposed on them by the white society, an identity that was meant to keep them below the standard level of humanity. Therefore, they took it upon themselves to introduce "The New Negro" to the world. Alain Leroy Locke who coined this term published The New Negro: An Interpretation in 1925 in which he anthologized pieces of African and African-American art and literature. He presented in the book philosophical notions about black culture that did not harden into rules but encouraged AfricanAmericans not to comply with unreasonable demands of the white society. The original identity they were looking for could be achieved by rejecting the academic conventions, formal rules and the standard discourse, a rejection that would lead to the articulation of the purely improvisational jazz music as an American icon in which black culture was incorporated.

Williams' descriptive poems can be studied in the light of Harlem's fashion of liberating individuals from stereotypical definitions. Hallberg notes that Williams gave up the more flattering position of the explainer for that of the descriptive poet, and considered description as limitation: "the descriptive poet is restrained by his task, he is the scribe for his subject, his office is to copy rather than transform" (Hallberg, 1978: 132). Although pure description, reduced to "copying" by Hallberg, seems to be the least challenging task for a poet, it signifies a reverence for the ontology of the world around us. This attitude can be justified if put in the proper context. The emphasis on the physicality of the objects in the world, or the absence of symbolism or an allusive language are the strategies used by Williams to lay the object bare, to free it from abstract connotations: the object does not refer to a world beyond, the physical entity of the object is respected not because it stands for its perfect counterpart in 
the platonic world of ideals, but simply because it is. In the "Young Sycamore", this attitude can best be observed:

\author{
I must tell you \\ This young tree \\ Whose round and firm trunk \\ Between the wet \\ Pavement and the gutter \\ (where water \\ Is trickling) rises \\ Bodily \\ Into the air with \\ One undulant \\ Thrust half its height- \\ And then \\ Dividing and waning \\ Sending out \\ Young branches on \\ All sides-(1-16)
}

The individuality of the plant is what matters to Williams. He does not take it upon himself to show the unification of all the phenomena of the universe but to stress the plurality of the things existing side by side in the universe. In his analysis of the pluralism found in Williams, Miller explains:

The young sycamore is itself, means itself. It is an object in space, separated from other objects in space, with its own sharp edges, its own innate particularity. The tree stands "between" the pavement and the gutter, but there is no assertion of an interchange between the three objects, no flow of a ubiquitous nature-spirit binding all things together. Things for Williams exist side by side in the world, and the poet here locates the sycamore by reference to the things closest to it. (1966: 3)

Williams himself has said often that he wants to rid the poem of "simile, for mere similarity implies difference that is minimized, or ignored entirely, for the sake of supporting partial likeness, while he wishes to display identity only within a maintained individuality" (Ostrom, 1966: 155). The sycamore, therefore, is not meant to be a symbol, neither does it refer to an abstract idea, rather it is reduced to its physical entity, to its ontological existence, merely in order to be. Williams liberates the sycamore from any imposed definition.

The Influence of the Discourse of Science and Technology

The descriptive style of Williams can be elucidated in the light of another cultural discourse, that of the scientific boom at the beginning of the $20^{\text {th }}$ century. The non-allusive language and the downto-earth treatment of the thing described are in line with the pragmatic outlook of science. The shadow of science in the realm of literature and more specifically in the poems of Williams is not limited to cursory mentions of the name of technological products. Williams observes the world with scientific attentiveness:

Williams's poetry persistently offers precise direct observation of people and landscapes, rather than treating the world as a dictionary of potential symbols for poetic expression, and many later American poets have also thought that poetry could respond to science's precision of observation by striving for a similar accuracy of report in their own medium (Middleton 215).

Celebration of the urban values such as industrial settings and technological achievements and mathematical outlook of the world appear in the poetry of the time. Lozowick (1927) says in "The Americanization of Art”:

The dominant trend in America of today, beneath all the apparent chaos and confusion is towards order and organization which find their outward sign and symbol in the rigid geometry of the 
American city: in the verticals of its smoke stacks, in the parallels of its car tracks, the squares of its streets, the cubes of its factories, the arc of its bridges, the cylinders of its gas tanks. (Lozowick, 1927: 18)

Mathematical and geometrical references in the poetic world of Williams are efforts to change the American space into American places where a distinctly American identity can be formulated. In "The Great Figure" for example, Williams looks at a mathematical figure and counts it as the discipline in a chaotic setting:

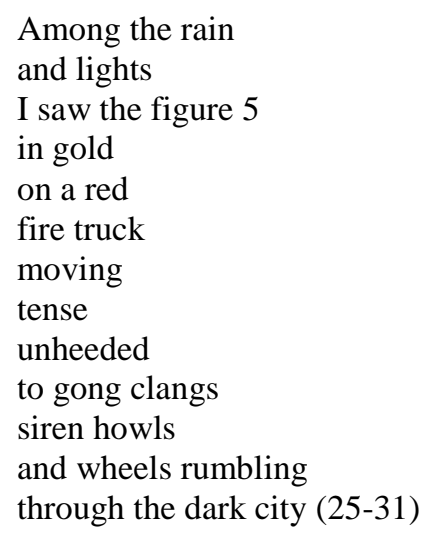

The golden color of the figure is in sharp contrast with the dark color of the city. Its glaze is centralized in a scene otherwise plagued with howls, unheeded movement and stormy weather. Therefore, the shining mathematical figure is the unifying element in the chaos of the dark city.

Another outlook used by Williams, that can be attributed to the scientific aura is the mobile gaze in some of Williams's poems in which the speaker describes what he sees during driving. In "The Right of Way" the speaker passes a number of scenes and gives snapshots of each; formalistically speaking, the frequency of the images do not form an interrelated whole, but disparate pictures:

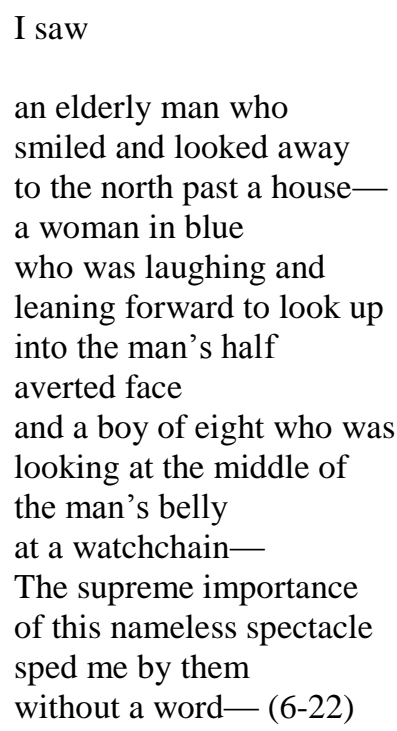

Scientific and technological progress is depicted in terms of moving in a car in which you can have only a transitory picture of the world, the quick movement representing change and dynamism against stagnation. Inseparable from the quick onward movement of science and technology is the fading out of the natural landscape and the human beings that are overtaken by the motorist. Therefore, "he is aggressively unreflective" in his quick review of what he comes upon on the way (Chatlos et al, 2006: 143). The indifferent tone of the speaker, and his detached stance are embedded within a progressseeking society that takes euphoric pride in onward movement and cares nothing for the unmoving. 
Mass production and consumer culture are the economic ideologies of the United States. Williams with his insistence on the anti-poetic, turns to everyday subjects, many of them categorized as the "pure products of America," such as refrigerators and automobiles. Williams does not sentimentalize such products but smoothly lets them be part and parcel of the poetic productions in modern American literature. In "This Is Just to Say" for example:

\author{
I have eaten \\ The plums \\ That were in \\ The icebox \\ And which \\ You were probably \\ Saving \\ For breakfast \\ Forgive me \\ They were delicious \\ So sweet \\ And so cold (16-21)
}

The domestic setting turns into the (anti)poetic world of Williams and the icebox is what provides the speaker with great pleasures. After the First World War, widespread use of electricity and mass production of technological house appliances, like refrigerator, naturally brought about a change of eating habits in the American people. The coldness of the plum in the poem is a luxury of modernism provided by the icebox. The poem ends with the adjective "cold" as if the final confession and justification of the speaker's transgression is due to the irresistible function of the electronic devicethe icebox - and not to the natural sweetness of the plum itself. The pleasure provided by the machine overtakes the pleasure provided by the natural fruit.

Conclusion

William Carlos Williams avoided the poetic diction of previous poetic periods and emphasized, often in hash images and an overtly frank language, the necessity of paying attention to objects that surrounded the Americans in early $20^{\text {th }}$ century in order to establish a down to earth identity for American poetry as distinct from the abstract symbolist agenda prevalent in late $19^{\text {th }}$ century European poetry. He targeted his poems not at the elite literati but at people who preferred to read poems written in the rhythm of typical American speech. Composing poetry at a time when T.S. Eliot was producing a highly allusive and connotative verse and Ezra Pound was putting a heroic effort to "make it difficult," Williams brought modern American poetry home to the general public.

\title{
WORKS CITED
}

Baker, C. 2004. The SAGE Dictionary of Cultural Studies. London: Sage Publication.

"Berlin Calls Jazz American Folk Music." 10 January 1925. The New York Times. 2.

Breslin, J. E. 1967. " Whitman and the Early Development of William Carlos Williams." PMLA vol. 82, no 7. 613-621

Chasar, M. D. 2007. “Everyday Reading: U.S. Poetry and Popular Culture, 1880-1945.” PhD Thesis, University of Iowa.

Chatlos, J. and S. Plattsburgh. 2006. "Automobility and Lyric Poetry: The Mobile Gaze in William Carlos Williams' 'The Right of Way'." Journal of Modern Literature vol. 30, no 1.140-54.

Dolin, S. 1993. "Enjambment and the Erotics of the Gaze in Williams's Poetry." American Imago vol. 50, no 1. 29-53.

Gee, J. P. 1985. "The Structure of Perception in the Poetry of William Carlos Williams: A Stylistic Analysis." Poetics Today vol. 6, no 3. 375-397.

Gilfoyle, T. J. 1998. "White Cities, Linguistic Turns, and Disneylands: The New Paradigms of Urban History." Reviews in American History vol. 26, no 1. 175-204.

Greenblatt, S. 1995. "Culture" In: Lentricchia, F. and McLaughlin, Th. (eds.), Critical Terms for Literary Study, Chicago: The University of Chicago Press, 225-232. 
von Hallberg, R. 1978. “The Politics of Description: W.C. Williams in the Thirties.” English Literary History vol. 45, no 1.131-151.

Heath, S. B. 1985. "Literacy and Change.” In: Tannen, D. (ed.), Georgetown University Roundtable on Language and Linguistics 1985. Washington, DC: Georgetown University Press, 287-88.

Hofstadter, M. 1977. “A Different Speech: William Carlos Williams' Later Poetry.” Twentieth Century Literature vol. 23, no 4. 451-466.

Kouwenhoven, J. A. 1998. "What's American about America.” In: O'Meally, R. (ed.) The Jazz Cadence of American Culture. New York: Columbia University Press, 123-136.

Lancaster, C. 1958. "The American Bungalow." The Art Bulletin vol 40, no 3. 239-253.

Locke, A. L. 1925. The New Negro: An Interpretation. New York: A. and C. Boni.

Lozowick, L. 1927. "The Americanization of Art." In: Machine-age Exposition : Catalogue. New York: Jane Heap, 18-19.

Marchand, R. 1985. Advertising and the American Dream: Making Way for Modernity, 1920-1940. Berkeley: University of California Press.

Menzin, J. 2014. "Cubism in Words: Broken Pieces in the Poetry of William Carlos Williams." William Carlos Williams Review vol. 31, no 2. 125-139.

Middleton, P. 2006. "Poets and Scientists." In: Fredman S.(ed.), A Concise Companion to Twentieth-Century American Poetry. Hoboken: Blackwell Publishing, 212-230.

Miller, J. H. 1966. William Carlos Williams: A Collection of Critical Essays. New Jersey: Prentice-Hall, Inc., Englewood Cliffs.

Moore, P. 1986. " William Carlos Williams and the Modernist Attack on Logical Syntax." ELH vol. 53, no 4. 895-916.

Morgan, F. 1991. "William Carlos Williams: Imagery, Rhythm, Form.” The Sewanee Review, vol. 55, no 4. 675690.

North, M. 1998. The Dialect of Modernism: Race, Language, and Twentieth-Century Literature. Oxford: Oxford University Press.

Ostrom, A. 1966. The Poetic World of Willam Carlos Williams. Carbondale and Edwardsville: Southern Illinois University Press.

Sayre, H. M. 1989. "American Vernacular: Objectivism, Precisionism, and the Aesthetics of the Machine." Twentieth Century Literature vol. 35, no 3. 310-342.

Singal, D. J. 1987. "Towards a Definition of American Modernism.” American Quarterly vol. 39, no 1. 7-26.

Solt, M. E. 1962. "William Carlos Williams: Idiom and Structure." The Massachusetts Review vol. 3, no 2. $304-$ 318.

Wells, C. W. 2007. "The Road to the Model T Culture, Road Conditions, and Innovation at the Dawn of the American Motor Age." Technology and Culture vol.48, no 3. 497-523.

Weatherhead, A. K. 1992. "William Carlos Williams: Prose, Form, and Measure." ELH vol. 33, no 1. 118-131.

Whiteman, P. 13 March 1927. "In Defense of Jazz and its Makers." The New York Times. 4.

Wigoder, M. 2002. "The 'Solar Eye' of Vision: Emergence of the Skyscraper-Viewer in the Discourse on Heights in New York City, 1890-1920.” The Journal of the Society of Architectural Historians vol.61, issue 2. 152-169.

Wilk, Ch. 2006. Modernism: Designing a New World 1914-1939. London: V\&A Publications.

Williams, W. C. 1954. “A Point for American Criticism(1929).” In: Selected Essays of William Carlos Williams. New York: Random House, Inc, 80-90.

-----. 1969. Selected Poems of William Carlos Williams. New York: New Directions Publishing Corporation.

----. 1997. “An Unpublished Letter on Modernism and American Poetics.” Ed. R. Buckeye. New England Review. vol. 18, no 2. 160-162. 